\title{
Relationship between microcephaly and Zika virus during pregnancy: a review
}

\author{
Gerusinete Rodrigues Bastos dos Santos ${ }^{1}$ \\ (iD) Francisca Bruna Arruda Aragão ${ }^{1}$ \\ Walder Jansen de Mello Lobão \\ Fabiano Rosário Lima ${ }^{3}$ \\ Luísa Marillac Ramos Lacerda de Andrade \\ Quesia Rodrigues Furtado ${ }^{5}$ \\ José Eduardo Batista 6
}

\begin{abstract}
1. Master in Adult and Child Health, Federal University of Maranhão (UFMA), São Luís, MA, Brasil. 2. Professor of the Pathology Department - UFMA and Master of Health Sciences, São Luís, MA, Brasil. 3. Nurse of the Family Health Strategy of the Municipality of Turilândia, MA, Brasil. 4. Physician from the Federal University of Maranhão (UFMA), Specialist in Family Health MS/UFMA, São Luís, MA, Brasil. 5. Graduated in Medicine from the Latin-American Private University - Upal, Cochabamba, Bolivia. 6. Professor of the Federal University of Maranhão (UFMA); Pathology Department and Doctor of Tropical Medicine, São Luís, MA, Brasil.
\end{abstract}

\section{SUMMARY}

AIM: the present study analysed the association between Zika-virus and microcephaly during the gestational period of women in Brazil. Methodology: Systematic reviews of intervention research, current publications of clinical investigations were used systematic search strategies in three electronic databases PubMed, SciELO and Google academic. The following keywords were used: Microcephaly, gestation, Zika-virus to perform the search, and 1020 articles were obtained after exclusion, 45 were left and 35 were eligible. The collection period was from 2004 to 2017. Results: Epidemiological data suggest a temporal association between the quantitative increase and the Zika-virus epidemic, especially in Northeast Brazil. It is not consensual to measure the cephalic perimeter curve to be considered. Conclusion: Given this, the application of techniques to accurately diagnose the relationship between causes and effects in the pathogenesis of Zika virus infection in the central nervous system should be prioritized.

KEYWORDS: Epidemics. Zika vírus. Microcephaly. Pregnancy.

\section{INTRODUCTION}

It is of expressive importance to know about the transmission process and ways to combat Zika fever, as well as how to explore the possibility of it being related to neurological diseases ${ }^{1}$. In summary, the Zika (ZIKV) spread in Brazil was caused by the migration of the vírus from the French Polynesia during the Confederations Cup in 2013 with the Tahitian delegation; this fact is confirmed by the genetic similarity of the viruses found in the mentioned countries and by the promotion of inappropriate sanitary conditions, the occurrence of several events with significant migratory activities, such as the 2014 World Cup, the rapid urbanization process and deforestation ${ }^{2}$.

Due to the progressive increase in incidence, the World Health Organization (WHO) launched an alert to declare an international emergency because of the increase in microcephaly in endemic zones with ZIKV virus proliferation ${ }^{3}$. The possible relationship between intrauterine infection by ZIKV and early microcephaly was first reported by physicians in the Brazilian Northeast. The sudden increase in these incidences was observed in the birth of children with 
microcephaly, and the arrival of this virus was then identified in the country. However, further evidence on the relationship between cause and effect is still necessary, ${ }^{4,5}$ but the fact is that when ZIKV enters the central nervous system (CNS), it breaks the protection of the blood-brain barrier, and this has already been demonstrated in animal studies ${ }^{1,6}$.

Other means of virus transmission have recently been discovered, in addition to the bite of the infected insect, through sexual contact or secretions (saliva, urine), which, together with the lack of vaccines or specific treatment, cause an important alarm in the population. Together, the absence of biological markers of exponential duration that make it possible to confirm the diagnosis, it increases the number of suspected cases and, consequently, false positive records ${ }^{1,7}$.

Microcephaly was established as a neonatal cephalic perimeter equal to or greater than 2 SD below the average in relation to gestational age and the gender of the child at birth. It is difficult to confirm the infection retroactively, considering that immunological and serological tests have the possibility of indicating a cross-reaction with other flaviviruses, especially the dengue virus ${ }^{8}$; there is also a remote possibility that microcephaly is not a consequence of Zika fever, as the pathophysiological gears by which the Zika virus has destabilized the central nervous system have not yet been completely unveiled, although there is an increasing epidemiological evidence that they are related, but one cannot be sure that it exists .

\section{SOURCE OF DATA}

This article, with a descriptive qualitative character, based the research on data available in digital collections, mainly through scientific articles published in an online environment.

The parameters for the eligibility and constitution of the synthesis were based on systematic reviews of intervention research, current publications of clinical investigations. Narrative reviews, overviews, essays, and meta-analyses were not included.

Systematic search strategies were used in three electronic databases: PubMed, SciELO and Google academic. The collection period was from December 2016 to January 2017, using the keywords microcephaly, gestation and Zika virus as descriptors, and articles were included in the English and Portuguese languages. As a result, 1,020 articles were obtained, and the repeated articles were subsequently excluded. The selection of articles was started by reading the abstracts to choose the ones of interest. Subsequently, the articles were read entirely by two reviewers for the analysis.

\section{SYNTHESIS OF DATA \\ EPIDEMIOLOGY OF THE ZIKA VIRUS}

The Zika virus (ZIKV) is a flavivirus mainly transmitted by the Aedes aegypti mosquito. Since May 2015, an outbreak of ZIKV infection has been identified in Brazil, associated with the growth of congenital microcephaly in new-borns (NB) in affected regions ${ }^{10}$.

The ZIKV RNA virus was found in the brain of a foetus with congenital microcephaly (11); in addition, it was also found in the amniotic fluid of two women with foetuses who had congenital microcephaly identified on prenatal ultrasound (3). These occurrences have raised concerns about the possibility that congenital microcephaly may be associated with the recent outbreak of ZIKV infection in Brazil, but only image data restricted to cerebral anomalies are available that may be linked to intrauterine infection by ZIKV ${ }^{12}$.

In West Africa and Asia (Southeast Asia), although the virus has been found in monkeys (Cercopithecus aethiops and Erythrocebus patas), serological investigations point to a possible circulation in several species of vertebrate animals, along with large mammals such as orangutans, elephants, zebras, buffaloes and rodents ${ }^{3}$.

Incidents and the geographical spread of outbreaks without identifying the incidence in non-human primates strengthens the premise that humans show essential importance as hosts that amplify the ZIKV transmission cycle. However, there are still several gaps in the stages of ZIKV transmission to be understood, both in urban and wild environments, and although there are signs of infection, with detection of ZIKV-specific antibodies, and it has been verified in rodents, there is no evidence that there are other non-primate reservoirs ${ }^{13}$.

\section{DIAGNOSTIC METHODS OF THE ZIKA VIRUS}

The test for ZIKV is within the measures determined by the Ministry of Health in the protocol that establishes the preliminary procedures to be adopted for the surveillance of cases of microcephaly in Brazi ${ }^{10}$. In most cases, at the laboratory level, the haemogram shows no changes, and may possibly indicate leukopenia, lymphocytosis and thrombocytopenia. The definitive diagnosis is made through costly and rarely available tests, in some reference centres only, by the reverse tran- 
scriptase reaction followed by the polymerase chain reaction (RT-PCR) ${ }^{7}$.

The Elisa technique (serology) can be effective after the symptomatic period of the disease, gaining relevance as a retrospective diagnosis for epidemiological purposes. However, it should be noted that serology may have a diminished characteristic in regions where distinct flaviviruses occur, and in this context, RT-PCR is of greater importance. The Brazilian government has invested efforts in the perspective of providing serological tests for suspected cases of the disease ${ }^{7}$.

However, there are no systematized forms of treatment guidance and performing them depends on considering the reports of other epidemics (Asian and African) and the experience with other arboviruses12. Treatment of ZIKV fever is based on resting, hydrating and symptomatic treatment. In this case, the use of non-hormonal anti-inflammatory drugs is contraindicated, and those that are frequently used for rheumatologic diseases should be re-evaluated ${ }^{12}$.

Because of the juxtaposition of symptoms in distinct arboviruses, the characteristic diagnosis of ZIKV in tropical regions presents a challenge. In addition, during the rainy season, other diseases should also be observed, such as leptospirosis ${ }^{12,13}$. For healthcare teams, it is essential that they have specific training and greater attention to signs and symptoms that indicate an atypical evolution or greater severity of the infection, besides the availability of a continuing medical education on the subject, since a large part of the patients are conducted clinically by general practitioners with maximum capacity being reached at emergency rooms ${ }^{14}$.

Stages of intrauterine development of the central nervous system (CNS) and microcephaly-associated disorders

The development of the central nervous system in humans begins in the period of gastrulation, around the 14th embryonic day, when a thickening of the ectodermal membrane occurs, which will give rise to the neural plaque. From there, two sequential processes will occur: neural tube formation and forebrain growth ${ }^{15}$.

The proliferation phase is extremely complicated and extensive. It begins from the 2nd to the 4th month of gestation with the proliferation of neurons and the formation of glial radial cells, extending from the 5th month and until the first year of life. The beginning of the process is characterized by the stem cells of the germinal matrix dividing symmetrically, forming the neural-glial proliferative units, which, in turn, are distributed in the periventricular zone15. Then an asymmetric division begins, in which each stem cell gives rise to another stem cell and a postmitotic neuronal cell. It is the asymmetrical division that establishes the dimension of the proliferative unit16; the postmitotic neurons migrate to the extension of the radial glia to form the various layers of the cerebral cortex. Approximately $1 / 3$ of the neurons do not use the radial glial frame and migrate tangentially in the cortical direction ${ }^{14}$.

In the course of the migration, neurons transit through neurons that are in position in the cortex, leading to a lamination in which the last neurons that return in the cortical zone take position on the outermost surface of the cortex. This final order with six layers, histologically different, aggregates an exceptional plurality of neuronal subtypes, which have the utility of blocks for the constitution of a powerful neural circuit ${ }^{14}$.

Modifications of the cerebral cortex development are like a grouping of differentiated malformations with pathogenesis still undefined, and among the cortical malformations a subset of pathologies has been linked to changes in cellular migration and to neurodifferentiation, among them the lysencephaly, polymicrogyria and focal cortical dysplasia ${ }^{14}$.

Several environmental factors have already been detected as responsible for cortical malformations; disorders in cortical development of the foetus may occur due to the mother's exposure to agents such as ethanol, some acids, anticonvulsant drugs, mercury, radiation and viral agents, among others, in the gestational phase ${ }^{17}$.

\section{STAGES OF INTRAUTERINE DEVELOPMENT OF THE CENTRAL NERVOUS SYSTEM (CNS) AND MICROCEPHALY-ASSOCIATED DISORDERS}

The development of the central nervous system in humans begins in the period of gastrulation, around the $14^{\text {th }}$ embryonic day, when a thickening of the ectodermal membrane occurs, which will give rise to the neural plaque. From there, two sequential processes will occur: neural tube formation and forebrain growth ${ }^{15}$.

The proliferation phase is extremely complicated and extensive. It begins from the $2^{\text {nd }}$ to the $4^{\text {th }}$ month of gestation with the proliferation of neurons and the formation of glial radial cells, extending from the $5^{\text {th }}$ month and until the first year of life. The beginning of the process is characterized by the stem cells of the germinal matrix dividing symmetrically, forming the neural-glial proliferative units, which, in turn, are distributed in the periventricular zone ${ }^{15}$. Then an asymmetric division be- 
gins, in which each stem cell gives rise to another stem cell and a postmitotic neuronal cell. It is the asymmetrical division that establishes the dimension of the proliferative unit ${ }^{16}$; the postmitotic neurons migrate to the extension of the radial glia to form the various layers of the cerebral cortex. Approximately $1 / 3$ of the neurons do not use the radial glial frame and migrate tangentially in the cortical direction ${ }^{14}$.

In the course of the migration, neurons transit through neurons that are in position in the cortex, leading to a lamination in which the last neurons that return in the cortical zone take position on the outermost surface of the cortex. This final order with six layers, histologically different, aggregates an exceptional plurality of neuronal subtypes, which have the utility of blocks for the constitution of a powerful neural circuit ${ }^{14}$.

Modifications of the cerebral cortex development are like a grouping of differentiated malformations with pathogenesis still undefined, and among the cortical malformations a subset of pathologies has been linked to changes in cellular migration and to neurodifferentiation, among them the lysencephaly, polymicrogyria and focal cortical dysplasia ${ }^{14}$.

Several environmental factors have already been detected as responsible for cortical malformations; disorders in cortical development of the foetus may occur due to the mother's exposure to agents such as ethanol, some acids, anticonvulsant drugs, mercury, radiation and viral agents, among others, in the gestational phase ${ }^{17}$.

\section{AETIOLOGY AND DIFFERENTIAL DIAGNOSIS OF MICROCEPHALY}

It is more pertinent to approach microcephaly, due to the diverse forms, aetiologies and clinical expressions. The pathogenesis of microcephaly is heterogeneous, including genetic causes in environmental factors that have a possible impact on neurodevelopment and thus end up influencing brain enlargement. Thus, any factors that may interfere in cell proliferation and/ or differentiation and cell death may lead to microcephaly; these factors can only reach the development of the brain or compromise other parts of the body, determining dimorphisms (syndromic microcephaly) ${ }^{18,19}$.

In order to simplify the clinical investigation and the differential diagnosis of microcephaly, one can first classify them based on the moment when the diagnosis is made. Thus, microcephaly can be listed in two categories: congenital and postnatal, which develops generally in the first two years of life ${ }^{18,19}$.
Microcephaly can be either genetic or acquired, comprehending exponentially damaging external/environmental factors to the brain. In acquired congenital microcephaly, the most aggressive factors play a role throughout the development of the brain in the intrauterine phase, including maternal infections (herpesviruses, cytomegalovirus, rubella, toxoplasmosis, syphilis, HIV and now possibly ZIKV conjugation), exposure to drug/substance toxicity (emphasis is placed on the mother's consumption of alcoholic beverages, foetal alcohol syndrome), irradiation, disruptive factors that end up interrupting normal brain growth, for example, hypoxic-ischemic syndrome, ischemia, haemorrhage, traumatic brain injury and nutritional deficiency (maternal malnutrition, placental insufficiency, hypothyroidism or folate deficiency in the mother) $)^{18,20}$.

Genetic congenital microcephaly may be linked to chromosomal diseases or to specific genes, such as in microcephaly primary hereditary (MCPH), historically known as microcephaly vera, in which at least 12 genes were detected as centrosome-associated proteins encoding $^{21,22}$. In this case, the term primary microcephaly corresponds to those in which the decrease of cerebral volume is first due to the reduction of the neuronal population along the neurogenesis ${ }^{23,24}$.

Among the genetic postnatal microcephaly linked to mutations (duplication, deletion mutation, fusion, insertion, circumstantial changes of amino acids) are those that derive from congenital metabolic errors, neurodegenerative diseases and distinct syndromes, such as: Pitt-Hopkins, Rubinstein-Taybi and Christianson's syndromes, Angelman's syndrome, and disorders related to MECP2 (Rett's syndrome)23.

\section{NEUROIMAGING AND ZIKV}

It was reported through a cranial CT scan that 23 children, 13 of them female, were affected by congenital microcephaly, with clinical and epidemiological data compatible with ZIKV congenital infection with TTC between September and December 2015, in Pernambuco, Brazil ${ }^{25}$. Cerebrospinal fluid samples were available for serological testing in seven children out of 23 , and the IgM antibody enzyme-linked immunosorbent assay for ZIKV was positive in the seven samples collected. The conclusions about the serological analyses of Torch infection (toxoplasmosis, rubella, cytomegalovirus and herpes simplex and others [syphilis, varicella, parvovirus and human immunodeficiency virus]) were negative in all 23 children $^{25}$. 
In the CT-scan images an average age of 36 days after birth (ranging from 3 to 5 months) was identified; intracranial calcifications were observed in all children, especially in the frontal lobe $(69 \%$ to $78 \%$ ) and the parietal lobe (in $83 \%$ to $87 \%)^{26}$. Calcifications were found mainly at the corticomedullary junction (53\% to $86 \%$ ), with basal ganglia (in $57 \%$ to $65 \%$ ) and in the thalamus (39\% to $43 \%$ ); the configuration of the calcifications was basically punctate (72\% to $100 \%$ ), distributed in the band format (in 56\% to $75 \%)$; ventriculomegaly was found in all children and classified as severe in the majority of cases (53\%), and it covered only the lateral ventricles in $43 \%{ }^{25}$.

The children, in their totality, had an overall reduction in the constitution of gyri of the severe cerebral cortex in $78 \%$ of the cases; cerebellar hypoplasia was present in 17 of the children (74\%), involving only one cerebellar hemisphere in three children, in which, in two of them, the brainstem was globally hypoplastic. Abnormal hypodensity of the white matter occurred in all children and in $87 \%$ of them there was diffuse involvement of all the cerebral lobes; chronic encephalomalacia alterations of ischemic stroke were identified in the vascular territory of the left middle cerebral artery ${ }^{25}$.

Intrauterine infection by ZIKV is associated with potential brain abnormalities, including calcifications, global reduction of cortical gyri constitution, ventriculomegaly, and white matter abnormalities, although it is not possible to definitively determine whether ZIKV infection occurred during the foetal development in the 23 children observed ${ }^{25}$.

The results achieved are non-specific and may be observed in other congenital viral infections; the fact that there is an overall reduction in the constitution of cortical gyri and hypermyelination of the white matter or dysmyelination in all infants and cerebellar hypoplasia in most of them suggests that ZIKV may be related to an interruption in brain development rather than destruction of the brain itself. ${ }^{27}$

\section{RELATIONSHIP BETWEEN ZIKV AND MICROCEPHALY}

The attention given to the association of this infection is due to the increase of incidences of apparent microcephaly in foetuses born to mothers infected with $\mathrm{ZIKV}^{11}$ and to numerous studies reporting this association (Table 1). This fact can be identified in the case re- port of a pregnant woman who was affected by a febrile illness with eruption, already at the end of the first trimester of pregnancy, during her stay in Brazil ${ }^{11,28}$.

An ultrasonography was performed when she crossed the period corresponding to 29 weeks of pregnancy, revealing microcephaly with calcifications in the foetal brain and placenta. After the mother's request for pregnancy termination, the foetal autopsy was performed and microcephaly (anomalously small brain) was identified, with near-integral agitation, hydrocephalus and multifocal dystrophic calcifications in the cortex and subcortical white matter, associated with cortical displacement and mild focal inflammation; ZIKV was found in foetal brain tissue in the RT-PCR assay, with accurate results when placed under electron microscopy, that is, the complete genome of ZIKV was reconstituted from the foetal brain"1"

Another finding occurred with the discovery of cases in the Northeast of Brazil, a region in which the Ministry of Health declared a state of emergency. Occurrences were identified in women in the first months of gestation of children diagnosed with microcephaly, whose correspondence is equivalent to the highest occurrence levels in the region and were not correlated with family history of genetic inheritance or standardized tests of other infections ${ }^{26}$.

The Ministry of Health, through the Evandro Chagas Institute (IEC), made the causal link when it isolated the ZIKV from the brain by identifying it in the CSF, brain and fragments of various viscera (heart, lung, liver, spleen and kidney) of a new-born child who died after its birth ${ }^{26}$.

To clarify the causal association, we analysed the amniotic fluid of two pregnant women from Paraíba with a history of exanthematous disease and foetuses detected with microcephaly on foetal ultrasonography ${ }^{29}$.

From there, additional studies have been carried out to fully sequence the virus isolated from amniotic fluid, in which phylogenetic analysis has shown that the virus shares between $97 \%$ and $100 \%$ of its genomic identity with Asians isolated in the outbreak of French Polynesia, and that the findings of the viral genome in the patients for a few weeks after the acute phase suggest that the intrauterine viral load results from a persistent response ${ }^{30}$.

As described above, genomic alterations of the virus should be considered as a possibility of a new cause until more cases with greater evidence are identified and diagnosed, since the possibility of other aetiologies cannot be disregarded ${ }^{11}$. 


\section{DISCUSSION}

The population has been alarmed about the possibility of an association between ZIKV disease in women in the gestational phase and the development of microcephaly ${ }^{13,28}$. It is a disorder that occurs in the stage of neuronal dissemination, which processes early during gestation ( $3^{\text {rd }}$ and $4^{\text {th }}$ month) and, in specific cases, appears to coincide with the symptoms of maternal infection. The criteria for definitively certifying microcephaly have not been used uniformly, and since there are clear sub-notifications of these occurrences in Brazil, it is not easy to determine

TABLE 1 - DESCRIPTION OF THE MAIN STUDIES ON THE ASSOCIATION BETWEEN ZIKA VIRUS AND MICROCEPHALY INCLUDED IN THIS RESEARCH

\begin{tabular}{|c|c|c|}
\hline Name of the author & Purpose of the study & Conclusion \\
\hline $\begin{array}{l}\text { Bell et al. Zika virus infection of the } \\
\text { central nervous system of mice, } 1971 \text {. }\end{array}$ & $\begin{array}{l}\text { To verify the correlation between the } \\
\text { virus and microcephaly by intracerebral } \\
\text { inoculation of } 5 \text {-week old new-born mice } \\
\text { with zika virus. }\end{array}$ & $\begin{array}{l}\text { It identified that the replication of the astroglial cells } \\
\text { is associated with the destruction of the neurons } \\
\text { indicating the infection. }\end{array}$ \\
\hline $\begin{array}{l}\text { Schuler-Faccini et al. Possible association } \\
\text { between Zika virus infection and } \\
\text { microcephaly, } 2015 \text {. }\end{array}$ & $\begin{array}{l}\text { Task force report to investigate } \\
\text { association between microcephaly and } \\
\text { zika virus during gestation from registry } \\
\text { with incidence (cephalic circumference } \geq \\
2 \text { standard deviations [SD] below average } \\
\text { for gender and gestational age). }\end{array}$ & $\begin{array}{l}\text { Fourlimitationswere identified: the historical prevalence } \\
\text { of children with microcephaly in Brazil was lower than } \\
\text { the estimates; before the alert, despite descriptions of } \\
\text { congenital anomalies reported, the cephalic perimeter } \\
\text { was not routinely recorded; there were cases in which } \\
\text { there was no laboratory confirmation, resulting in } \\
\text { an incorrect classification and, finally, there are no } \\
\text { comments on other characteristics of the intrauterine } \\
\text { infections. }\end{array}$ \\
\hline $\begin{array}{l}\text { Broutet et al. Zika virus as a Cause of } \\
\text { Neurologic Disorders, } 2016 .\end{array}$ & $\begin{array}{l}\text { To analyse how and through which } \\
\text { mechanisms zika virus infections can } \\
\text { affect the nervous system. }\end{array}$ & $\begin{array}{l}\text { Causal relationships cannot be substantiated in } \\
\text { epidemiological studies, but these factors help to } \\
\text { identify the strength of possible causal links. }\end{array}$ \\
\hline $\begin{array}{l}\text { Hazin et al. Computed Tomographic } \\
\text { Findings in Microcephaly Associated with } \\
\text { Zika Virus, } 2016 .\end{array}$ & $\begin{array}{l}\text { To investigate the association between } \\
\text { progressive incidences of new-borns } \\
\text { with congenital microcephaly in regions } \\
\text { affected by ZIKV in Brazil. }\end{array}$ & $\begin{array}{l}\text { Intrauterine ZIKV infection appears to be associated } \\
\text { with severe brain anomalies, including calcifications, } \\
\text { cortical hypogria, ventriculomegaly, and white matter } \\
\text { abnormalities, although we cannot determine with } \\
\text { certainty when ZIKV infection may have occurred } \\
\text { during foetal development. }\end{array}$ \\
\hline $\begin{array}{l}\text { Jernej et al. Associação entre Zika Vírus e } \\
\text { Microcefalia, } 2016 .\end{array}$ & $\begin{array}{l}\text { Case report on the vertical transmission } \\
\text { of zika virus (ZIKV) in a woman probably } \\
\text { infected with ZIKV in the Northeast of } \\
\text { Brazil at the end of the first trimester of } \\
\text { pregnancy. Discussion includes imaging } \\
\text { details and foetal pathological and } \\
\text { virological analyses. }\end{array}$ & $\begin{array}{l}\text { Foetal body weight of } 1,470 \mathrm{~g} \text { (percentile 5), length } \\
42 \mathrm{~cm} \text { (percentile 10), cephalic perimeter } 26 \mathrm{~cm} \text { ( } 1 \text { st } \\
\text { percentile). The only external anomaly noted was } \\
\text { microcephaly; placenta weighing } 200 \mathrm{~g} \text {, resulting in } \\
\text { weight ratio of foetal placenta of } 0.136 \text { (<percentile } \\
\text { 3). Macroscopic examination of the CNS revealed } \\
\text { microcephaly with a total brain weight of } 84 \mathrm{~g} \text { ( } 4 \\
\text { standard deviations below average). }\end{array}$ \\
\hline $\begin{array}{l}\text { Mlakar et al. Zika virus associated with } \\
\text { microcephaly, } 2016 .\end{array}$ & $\begin{array}{l}\text { Research the association through the } \\
\text { increased incidence of microcephaly in } \\
\text { foetuses born to mothers infected with } \\
\text { ZIKV. }\end{array}$ & $\begin{array}{l}\text { Near-complete agitation and internal hydrocephalus } \\
\text { of the lateral ventricles were observed with numerous } \\
\text { calcifications of variable size in the cortex and } \\
\text { subcortical white matter in the frontal, parietal and } \\
\text { occipital lobes. }\end{array}$ \\
\hline $\begin{array}{l}\text { Oliveira et al. Zika virus intrauterine } \\
\text { infection causes foetal brain abnormality } \\
\text { and microcephaly: tip of the iceberg?, } \\
2016 .\end{array}$ & $\begin{array}{l}\text { Case report to prove the relationship } \\
\text { between zika virus and microcephaly. }\end{array}$ & $\begin{array}{l}\text { Similar to other intrauterine infections, it is possible } \\
\text { that the reported cases of microcephaly represent only } \\
\text { the most affected children and that in new-borns of } \\
\text { lesser severity, it affects not only the brain but other } \\
\text { organs and it has not yet been diagnosed. }\end{array}$ \\
\hline $\begin{array}{l}\text { Tetro JA. Zika and microcephaly: } \\
\text { causation, correlation, coincidence? } 2016 .\end{array}$ & $\begin{array}{l}\text { Research on the increase in incidence in } \\
\text { the State of Pernambuco. }\end{array}$ & $\begin{array}{l}\text { Reduced brain size indicates microcephaly, although } \\
\text { the mechanisms of the zika virus pathogenesis appear } \\
\text { to be in line with the requirements. There is no concrete } \\
\text { evidence. }\end{array}$ \\
\hline $\begin{array}{l}\text { Ventura et al. Ophthalmological } \\
\text { findings in infants with microcephaly } \\
\text { and presumable intrauterus Zika virus } \\
\text { infection, 2016. }\end{array}$ & $\begin{array}{l}\text { Research based on the report of a } 20 \text {-fold } \\
\text { increase in the prevalence of microcephaly } \\
\text { in Brazil, in which the Ministry of Health } \\
\text { associated this abnormal prevalence with } \\
\text { the transmission of the maternal-foetal } \\
\text { zika virus (ZIKV). }\end{array}$ & $\begin{array}{l}\text { Patients presented normal anterior segment and } \\
\text { important abnormalities of the macular nerve and } \\
\text { optic nerve. Other studies will evaluate the visual } \\
\text { significance of these changes. }\end{array}$ \\
\hline
\end{tabular}


exactly whether the incidence of this pathology has really increased ${ }^{18,21}$. In addition, accessible neuroimaging studies show that other malformations of foetal cortical development are also present, as well as diffuse calcifications (neuronal death), suggesting an extended duration of the virus pathogenesis in the CNS or a vulnerability of more phases of cortical development ${ }^{4,15,16,29}$.

If we consider the widespread diffusion of Aedes aegypti in the country and that the methods adhered to control the growth of the vector are slow to show results, it is expected that the incidence of ZIKV infection requires prioritizing the search for more integrated knowledge about the pathology and the etiological agent. Current studies suspect that changes in the molecular components of ZIKV, especially protein $\mathrm{E}$, which is on the surface of the virus, could be correlated with an exponential worsening of ZIKV, thus reinforcing its neurotropism and its ability to affect humans ${ }^{31}$.

The situation requires multiple interpretations and multidisciplinary actions to control the vector and the infection by the ZIKV, through the awareness of the people (the paediatrician plays a leading role in this process). It is true that ZIKV can overcome placental blockage and affect amniotic fluid and foetal tissues32; however, it is a priority to calm pregnant women, since it cannot be said that this increase in microcephaly reports is only associated with the virus, since many suspicious cases at the beginning have already been ruled out ${ }^{11}$.

The cases confirmed in the laboratory are inferior in comparison to the large index of notifications. Regardless, the means of prevention are still essential and should be identified, but the tests available for laboratory diagnosis of ZIKV infection in the acute or subsequent phase are still very limited. The difficulty of confirming or excluding infection still hinders the understanding of the natural history of the disease, its association with microcephaly and Guillain-Barre syndrome ${ }^{33}$.

Because of the extreme worldwide attention to the teratogenic potential of the Zika infection, there is a greater commitment to the development of more affordable and more specific tests, such as serology that represent a lower risk of cross-reactivity ${ }^{34}$.

In short, it is evident that there is a temporal association between the quantitative increase in the notification of cases of microcephaly and the ZIKV epidemic, especially in Northeast Brazil. However, the advancement of diagnostic techniques that reaffirm the relationship between cause and effect, the mechanism and infectious pathogenesis of ZIKV in the central nervous system and the diagnostic parameters more specifically established to identify the cases to be recognized should still be investigated with priority ${ }^{33}$.

\section{ASSOCIATES}

GRB dos Santos and FBA Aragão contributed to the construction of the object of study, definition of objectives and methodology, data collection, processing, analysis and writing of the article. LMR de Andrade and FR Lima participated in the study and their specific contribution was in the drafting of the manuscript and in its critical review regarding the content. WJM Lobão and QR Furtado participated in the analysis and interpretation of the results and in the proofreading. JE Batista participated in the study design, in the preparation and orientation of the research, in the critical review and in the approval of the final version of the article submitted for publication.

\section{RESUMO}

OBJETIVO: O presente estudo analisou a associação entre Zika vírus e microcefalia durante o período gestacional de mulheres no Brasil. metodologiA: Revisões sistemáticas de pesquisas de intervenção, publicações atuais de investigações clínicas. Foram utilizadas estratégias de buscas sistemáticas em três bases de dados eletrônicos: PubMed, SciELO e Google acadêmico. Utilizaram-se as palavras-chave microcefalia, gestação e Zika vírus para realizar a busca, sendo obtidos 1.020 artigos. Após a exclusão, restaram 45 e na elegibilidade, 35. O período da coleta foi de 2004 a 2017. Resultados: Os dados epidemiológicos preconizam uma associação temporal entre a ampliação do quantitativo e epidemia de Zika vírus, especialmente no Nordeste do Brasil. Não é consensual a mensuração da curva de perímetro cefálico a ser considerada. CONCLUSÃo: Visto isso, deve ser priorizada a aplicação de técnicas para diagnosticar com precisão as relações entre causas e efeitos na patogênese da infecção pelo Zika vírus no sistema nervoso central.

PALAVRAS-CHAVE: Epidemias. Zika vírus. Microcefalia. Gestação. 


\section{REFERENCES}

1. Musso D. Zika Virus transmission from French Polynesia to Brazil. Emerg Infect Dis. 2015;21(10):1887.

2. Negras L, Luz DTA. Vieira: a pluma e a voz. Letras. 2016;26:06.

3. Schuler-Faccini L, Ribeiro EM, Feitosa IM, Horovitz DD, Cavalcant DP, Pessoa A, et al; Brazilian Medical Genetics Society-Zika Embryopathy Task Force. Possible association between zika virus infection and microcephaly - Brazil, 2015. MMWR Morb Mortal Wkly Rep. 2016;65(3):59-62

4. Butler D. Zika virus: Brazil's surge in small-headed babies questioned by report. Nature. 2016;530(7588):13-4.

5. Dick GW, Kitchen SF, Haddow AI. Zika virus. I. Isolations and serological specificity. Trans R Soc Trop Med Hyg. 1952;46(5):509-20.

6. Bell TM, Field El, Narang HK. Zika virus infection of the central nervous system of mice. Arch Gesamte Virusforch. 1971;35(2):183-93.

7. Zanluca C, Melo VC, Mosimann AL, Santos GI, Santos CN, Luz K. First report of autochthonous transmission of Zika virus in Brazil. Mem Inst Oswaldo Cruz. 2015;110(4):569-72.

8. Herling JD, Vieira RG, Becker TOF, Souza VAI, Cortela DCB. Infecção por Zika Vírus e nascimento de crianças com microcefalia: revisão de literatura. Revista Ciência e Estudos Acadêmicos de Medicina. 2016:5:59-75

9. Broutet $N$, Krauer F, Riesen M, Khalakdina A, Almiron M, Aldighieri $\mathrm{S}$, et al. Zika virus as a cause of neurologic disorders. N Engl J Med. 2016;374(16):1506-9.

10. Custo Greig LF, Woodworth MB, Galazo MJ, Padmanabhan H, Macklis JD. Molecular logic of neocortical projection neuron specification, development and diversity. Nat Rev Neurosci. 2013;14(11):755-69.

11. Mlakar J, Korva M, Tul N, Popović M, Poljšak-Prijatelj M, Mraz J, et al. Zika virus associated with microcephaly. N Engl J Med. 2016;374(10):951-8.

12. Caveião $C$. Vírus Zika suas complicações relacionadas à microcefalia $e$ Guillain-Barré. Saúde. 2016;1(15):3-6.

13. Hayes EB. Zika virus outside Africa. Emerg Infect Dis. 2009;15(9):134750.

14. Martin-Loeches I, Torres A, Rinaudo M, Terraneo S, de Rosa F, Ramirez $P$, et al. Resistance patterns and outcomes in intensive care unit (ICU)-acquired pneumonia. Validation of European Centre for Disease Prevention and Control (ECDC) and the Centers for Disease Contro and Prevention (CDC) classification of multidrug resistant organisms. J Infect. 2015;70(3):213-22.

15. Volpe J. Viral, protozoan, and related intracranial infections. Neurology of the newborn. 4th ed. Philadelphia: WB Saunders; 2001. p.737-47.

16. Rakic P. A small step for the cell, a giant leap for mankind: a hypothesis of neocortical expansion during evolution. Trends Neurosci. 1995;18(9):383-8

17. Golden |A. Cell migration and cerebral cortical development. Neuropathol Appl Neurobiol. 2001;27(1):22-8.

18. Ashwal S, Michelson D, Plawner L, Dobyns WB; Quality Standards Subcommittee of the American Academy of Neurology and the Practice Committee of the Child Neurology Society. Practice parameter: Evaluation of the child with microcephaly (an evidence-based review) report of the Quality Standards Subcommittee of the American Academy of Neurology and the Practice Committee of the Child Neurology Society. Neurology. 2009;73(11):887-97

19. Passemard S, Verloes A, Billette de Villemeur T, Boespflug-Tanguy O, Hernandez K, Laurent M, et al. Abnormal spindle-like microcephaly-associated (ASPM) mutations strongly disrupt neocortical struc- ture but spare the hippocampus and long-term memory. Cortex. 2016;74:158-76.

20. Tetro JA. Zika and microcephaly: causation, correlation, or coincidence? Microbes Infect. 2016;18(3):167-8.

21. Faheem M, Naseer MI, Rasool M, Chaudhary AG, Kumosani TA, Ilyas $A M$, et al. Molecular genetics of human primary microcephaly: an overview. BMC Med Genomics. 2015;8(Supl 1):S4.

22. Hussain MS, Baig SM, Neumann S, Peche VS, Szczepanski S, Nürnberg $G$, et al. CDK6 associates with the centrosome during mitosis and is mutated in a large Pakistani family with primary microcephaly. Hum Mol Genet. 2013;22(25):5199-214.

23. Woods CG. Human microcephaly. Curr Opin Neurobiol. 2004;14(1):112-7.

24. Thornton GK, Woods CG. Primary microcephaly: do all roads lead to Rome? Trends Genet. 2009;25(11):501-10.

25. Hennessey M, Fischer M, Staples JE. Zika virus spreads to new areas region of the Americas, May 2015-January 2016. MMWR Morb Mortal Wkly Rep. 2016; 65(3):55-8.

26. Kindhauser MK, Allen T, Frank V, Santhana RS, Dye C. Zika: the origin and spread of a mosquito-borne virus. Bull World Health Organ. 2016;94(9):675-86C.

27. Jackson AS, Pollock ML. Generalized equations for predicting body density of men. Br | Nutr. 1978;40(3):497-504.

28. Villar J, Cheikh Ismail L, Victora CG, Ohuma EO, Bertino E, Altman DG, et al. International standards for newborn weight, length, and head circumference by gestational age and sex: the Newborn Cross-Sectional Study of the INTERGROWTH-21st Project. Lancet. 2014;384(9946):857-68.

29. Cofré F. Zika virus intrauterine infection causes fetal brain abnormality and microcephaly: tip of the iceberg? Rev Chilena Infectol. 2016;33(1):96

30. Calvet G, Aguiar RS, Melo ASO, Sampaio SA, Filippis I, Fabri A, et al. Detection and sequencing of Zika virus from amniotic fluid of fetuses with microcephaly in Brazil: a case study. Lancet Infect Dis. 2016;16(6):653-60.

31. Faye O, Freire CC, lamarino A, Faye O, Oliveira JV, Diallo M, et al. Molecular evolution of Zika virus during its emergence in the 20th century. PLoS Negl Trop Dis. 2014;8(1):e2636.

32. Besnard M, Lastere S, Teissier A, Cao-Lormeau V, Musso D. Evidence of perinatal transmission of Zika virus, French Polynesia, December 2013 and February 2014. Euro Surveill. 2014;19(13). pii: 20751.

33. Malone RW, Homan I, Callahan MV, Glasspool-Malone |, Damodaran L, Schneider AB, et al. Zika virus: medical countermeasure development challenges. PLoS Negl Trop Dis. 2016;10(3):e0004530.

34. Lucey DR. Time for global action on Zika virus epidemic. BMJ. 2016;352:i781.

35. Hazin AN, Poretti A, Di Cavalcanti Souza Cruz D, Tenorio M, van der Linder A, et al. Computed Tomographic findings in microcephaly associated with zika vírus. N Engl J Med. 2016: 374(22): 2193-5.

36. Mlakar J, Nova M, Tul N, Popovic M, Poljšak-Prijatelj M, et al. Zika virus associated with microcephaly. N Engl J Med. 2016; 374:975-958.

37. Oliveira Melo AS, Malinger G, Zimenes R, Azenjnfeld PO, Alves Sampaio S, Bispo de Filippis AM. Zika vírus intrauterine infection causes foetal brain abnormality and microcephaly: tip of the iceberg ? Ultrasound Obstet Gynecol. 2016; 47(1):6-7.

38. Ventura CV, Maia M, Ventura BV, Linden VV, Araujo EB, et al. Ophthalmological findings in infants with microcephaly and presumable intra-uterus Zika virus infection. Arq Bras Oftalmol. 2016; 79(1):1-3. 